\title{
Dendrometric characterization of Cupressus lusitanica mill. planted under Pinus taeda L. shelter in southern Brazil
}

Larissa Regina Topanotti ${ }^{1 * i \mathrm{D}}$, Douglas Rufino Vaz ${ }^{2 \mathrm{D}}$, Mário Dobner Jr. ${ }^{\text {iD }}$, Marcos Felipe Nicoletti ${ }^{2 \mathrm{DD}}$

${ }^{1}$ Federal University of Santa Catarina, Curitibanos, Santa Catarina, Brazil ${ }^{2}$ State University of Santa Catarina, Lages, Santa Catarina, Brazil

\section{FOREST MANAGEMENT}

\section{ABSTRACT}

Background: We analyzed if $C$. Iusitanica can be planted in a shelterwood system with $P$. taeda as the shelter stratum. The study was conducted in a 13-yr-old C. lusitanica stand under P. taeda canopy in Southern Brazil. Samples of these trees were measured in terms of diameter at breast height (DBH), total height, individual volume, and crown projection area. The species' growing space efficiency (GSE) was also analyzed. A 10-meters distance criterion from $P$. taeda trees was applied to check their influence on C. Iusitanica growth behavior through correlation.

Results: The 36-yr-old $P$. taeda trees showed expressive means in the dendrometric variables, compatible with its age (mean DBH of $58 \mathrm{~cm}$, total height $30 \mathrm{~m}$, individual volume of $3.7 \mathrm{~m}^{3}$, and crown projection area of $128 \mathrm{~m}^{2}$ ). There was a statistically significant effect $(\mathrm{p}>0.05)$ of $P$. taeda cover on C. Iusitanica diameter (mean of $\sim 13 \mathrm{~cm}$ ). Although not significant, an effect of $P$. taeda canopy was also observed on C. Iusitanica height. The two species summed a basal area of $36.5 \mathrm{~m}^{2}$ ha-1 and a crown projection area of 34,209.2 $\mathrm{m}^{2}$ ha-1. A tendency of increasing GSE with increasing diameter was observed for both species.

Conclusion: These results show that a shelterwood with C. Iusitanica under P. taeda is possible, but further investigations with longer production cycles and with silvicultural treatments (i.e. thinnings and shelter removal) should be conducted for a better understanding of shelterwood systems with these species in southern Brazil in terms of growth performance and soil use sustainability.

Keywords: Forest management; growing space efficiency; forest mensuration; shelterwood; underplanting

\section{HIGHLIGHTS}

There was an effect ( $p>0.05$ ) of Pinus taeda trees on Cupressus lusitanica diameter (DBH). An effect of $P$. taeda cover on $C$. I usitanica height was also observed.

The growing space efficiency increased with increasing diameter for both species.

P. taeda trees showed a tendency of decreasing GSE with increasing crown projection area.

TOPANOTTI, L. R.; VAZ, D. R.; DOBNER JR, M.; NICOLETTI, M. F. Dendrometric characterization of Cupressus /usitanica mill. planted under Pinus taeda L. shelter in southern Brazil. CERNE, v. 27, e-102709, doi: 10.1590/01047760202127012709 


\section{INTRODUCTION}

Even though most of the world's forests are composed of uneven-sized mixed-species stands, forest management practices around the globe have focused on the development of monocultures to produce timber on a large scale, quickly and cheaply. However, social and environmental expectations have changed over the years (Pukkala and Gadow, 2012; O'hara, 2014), and, combined with concerns about biodiversity loss and climate change, they have intensified the need to manage forests for multiple ecosystem services and functions, including timber production and biodiversity maintenance (Biber et al., 2015; Raymond and Bédard, 2017).

One silvicultural system that has been applied mostly in European and North American forests (temperate) but also in other regions (tropical/subtropical, i.e. New Zealand) to promote the regeneration of key-species is the shelterwood silvicultural system. It is characterized by the maintenance of a canopy that is gradually removed (the residual trees are called "shelter trees") to promote the regeneration under it, particularly to establish shadetolerant late-successional species (Balandier et al., 2007; Pukkala and Gadow, 2012; Stokes et al., 2020).

The regeneration in a shelterwood system can be natural or artificial. The artificial is characterized by planting trees under an existing canopy, which is a process called underplanting. Besides improving regeneration, this practice is carried out to introduce new species, to increase the proportion of the desired species, or to enrich and diversify the forest structure (Scolforo, 1998; Kerr and Haufe, 2016).

The shelterwood system presents several silvicultural advantages, such as seedlings protection against adverse weather conditions, maintenance of soil moisture, erosion reduction, and better utilization of soil nutrients than on clear-cut (Kelty, 2006; Dey et al., 2012; Pukkala and Gadow, 2012; Kerr and Haufe, 2016). Another benefit of this system is the establishment of a next crop at an earlier stage since the shelter trees are completely harvested only when the overstory is well-established. Thirdly, the remaining mature trees on the cover layer increase their increment and produce larger and high-quality logs, so the system also provides harvest products from different species on different periods (Kelty 2006; Dobner Jr. et al., 2009; Stokes et al., 2020).

On the other hand, this system also presents some disadvantages. Some of them are related to management practices since they become more complex due to species diversity, especially to avoid damages in the understory due to shelter tree harvesting. Others are related to ecological and silvicultural aspects, such as the intensification of inter and intraspecific competition, the difficulty of estimating the species' growth, and a possible effect from the canopy trees on the growth of understory trees due to reduction in light level and, consequently, decrease in photosynthetic rates (Strand et al., 2006; Dobner Jr. et al., 2009; Kerr and Haufe, 2016; Stokes et al., 2020).

Although this technique has been applied in several countries around the world (Strand et al., 2006; Dey et al., 2012; Forbes et al., 2014; Kerr and Haufe, 2016; Stokes et al., 2020), in Brazil, underplanting to enrich the understory diversity has been applied only to natural forests, as studied by Venturoli et al. (2011). In 1981, the first experiment with exotic species in a shelterwood scheme was carried out in Brazil, where native valuable timber species were planted under Pinus taeda L. cover (Carvalho, 1984). After that, Dobner et al. (2009) also studied a shelterwood with $P$. taeda in the canopy and Eucalyptus dunnii Maiden in the understory, in southern Brazil. Their results showed that the shelter intensity decreased the damages caused by frosts, but there was also a decrease in height and collar diameter growth of E. dunnii due to the shelter.

The present study is probably the third research in Brazil about a shelterwood system using $P$. taeda as the canopy. As $P$. taeda is the most planted pine species in Southern Brazil, in monocultures, (Embrapa, 2014), there is potential to transform some of these stands into shelterwood systems if the practical outcomes from this system prove themselves advantageous. For small to medium-size private owners, the multilayer arrangement could represent several incomes from different times, especially from the large $P$. taeda trees that occupy the canopy for a longer time, and, consequently, increase their size and commercial value (Topanotti, 2021, unpublished data)

Thus, studies focused on the dendrometric characterization of shelterwood are crucial to verify its potential and to create a database about this system in Brazil. This research aimed to (i) describe dendrometric variables of Pinus taeda and Cupressus lusitanica in a 13year shelterwood in Santa Catarina, Brazil, (ii) evaluate the species' growing space efficiency (GSE), and (iii) evaluate the existence of correlation among C. Iusitanica variables and distance from $P$. taeda trees in this system. We analyzed the following overall hypothesis: C. Iusitanica can be planted in a shelterwood system with $P$. taeda in the canopy without constraints to its growth.

\section{MATERIALS AND METHODS}

\section{Site description}

The study was conducted in an experimental site established in the municipality of Capão Alto, south of Santa

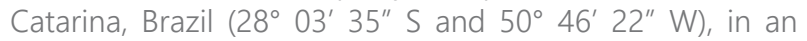
area of approximately 2 ha (Fig. 1). The climate is classified as Temperate Oceanic Climate (Cfb type), with an annual mean temperature of $13{ }^{\circ} \mathrm{C}$, an altitude of 1,000 m.a.s.l. and an annual rainfall mean of $1,750 \mathrm{~mm}$ (Alvares et al., 2013). The system component $P$. taeda was planted in 1982 (initial density of 2,500 trees.ha-1, spacing of $1.6 \times 2.5 \mathrm{~m}$ ) and thinned during several periods as a commercial stand until 2005 (23 years of age), when the surrounding stands were harvested. One stand was selected for this experiment, which was partially harvested to a stocking density of 60 trees per hectare. The second component, C. Iusitanica, was planted in 2005 under the $P$. taeda trees, in a spacing of 2.5 m x 2.5 m (1,600 stems.ha-1) (Fig. 2).

\section{Data collection}

Ten circular plots of $500 \mathrm{~m}^{2}$ were installed using the random start systematic sampling (Fig. 1). We measured 

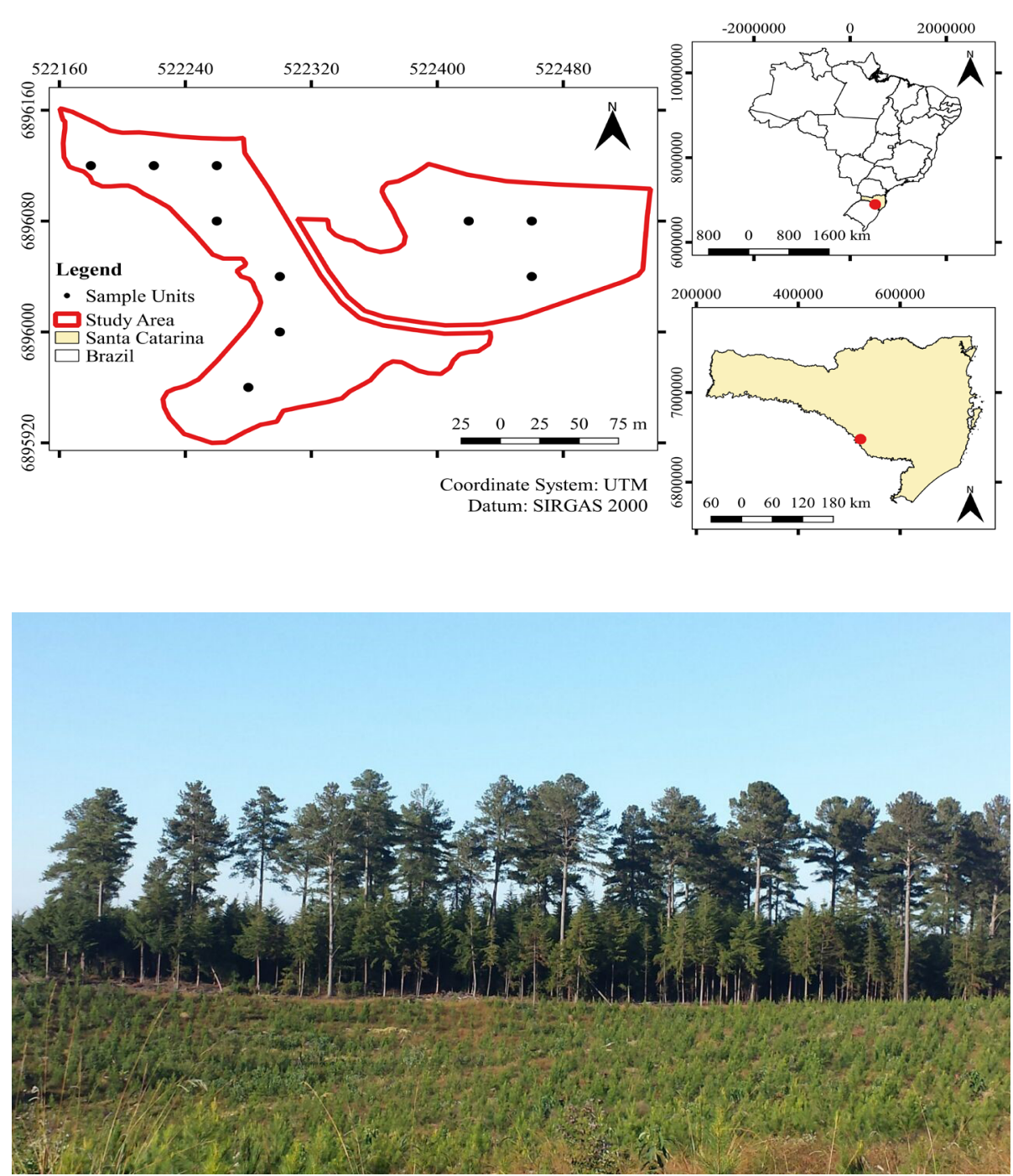

Fig. 1 Location of the study area and sample units. A) Study area and sample units; B) Brazil; C) Santa Catarina State.
Fig. 2 Cupressus lusitanica (lower layer) and Pinus taeda (upper layer) in a 13-yrold shelterwood system in Southern Brazil. diameter at breast height (DBH), total height (h), and crown radii (cr). The DBH was taken from all C. Iusitanica and $P$. taeda in the plots at $1.3 \mathrm{~m}$ above ground. The total height was measured for the $C$. Iusitanica trees in the planting line located in the center of each plot, plus five dominant C. Iusitanica trees (Fig. $3)$, which corresponded to a total sampling of 132 trees. Also, we obtained the total height of all the $P$. taeda trees found in the plots. The $\mathrm{DBH}$ and h were measured with a measuring tape and a digital hypsometer Vertex IV ${ }^{\circledR}$, respectively.

Regarding the crown measurements, four radii, from the stem until the end of the longestbranch, were measured following the cardinal directions. The crown survey included 94 C. Iusitanica individuals (all the trees in the central line) and all $P$. taeda trees, using a laser rangefinder TruPulse 200.

Based on the empiric diameter distribution of both species (class interval of $5 \mathrm{~cm}$ ), $33 \mathrm{C}$. Iusitanica and $16 P$. taeda trees were harvested and scaled in the following stem positions: $0.1 \mathrm{~m}, 0.3 \mathrm{~m}, 0.5 \mathrm{~m}, 0.7 \mathrm{~m}, 0.9 \mathrm{~m}, 1.3 \mathrm{~m}, 2 \mathrm{~m}$, and after that, every 1 meter up to the top of the tree, using a caliper. The volume per section was calculated through Smalian's and added to the top volume (cone) to get the individual total volume per tree. Five volume models were fitted to these data (Husch (1963), Spurr (1952), linearized SchumacherHall (1933), and Stoate (1945)), and due to their better performance, Schumacher-Hall (for $P$. taeda) and Spurr (for C. lusitanica) models were used to estimate the volume of the other trees, and, after that, the volume per hectare. The fitted volumetric equations obtained were the following: (1) (Schumacher-Hall - P. taeda) and (2) (Spurr - C. Iusitanica).

$$
L n v_{i}=-8.96+1.539 \ln d b h_{i}+1.802 \ln h_{i}+e_{i}
$$

$v_{i}=0.008828+0.0000318 d b h_{i}^{2}+e_{i}$

Besides these measurements, a sketch was made locating the $P$. taeda trees in the study area, taking their distance to the center of the plot. The $C$. lusitanica trees position in the plots was determined based on the plantation spacing (Fig. 3).

\section{Statistical Analyses}

All statistical analyses were conducted on Statistical Software $R{ }^{\circledR}$ version 3.6.0. The crown projection area was obtained through the following formula (Eq. 3), Where CA is the crown projection area, in $\mathrm{m}^{2} ; \mathrm{R}_{1} \ldots \mathrm{R}_{4}$ are the crown radii, in $\mathrm{m}$. 


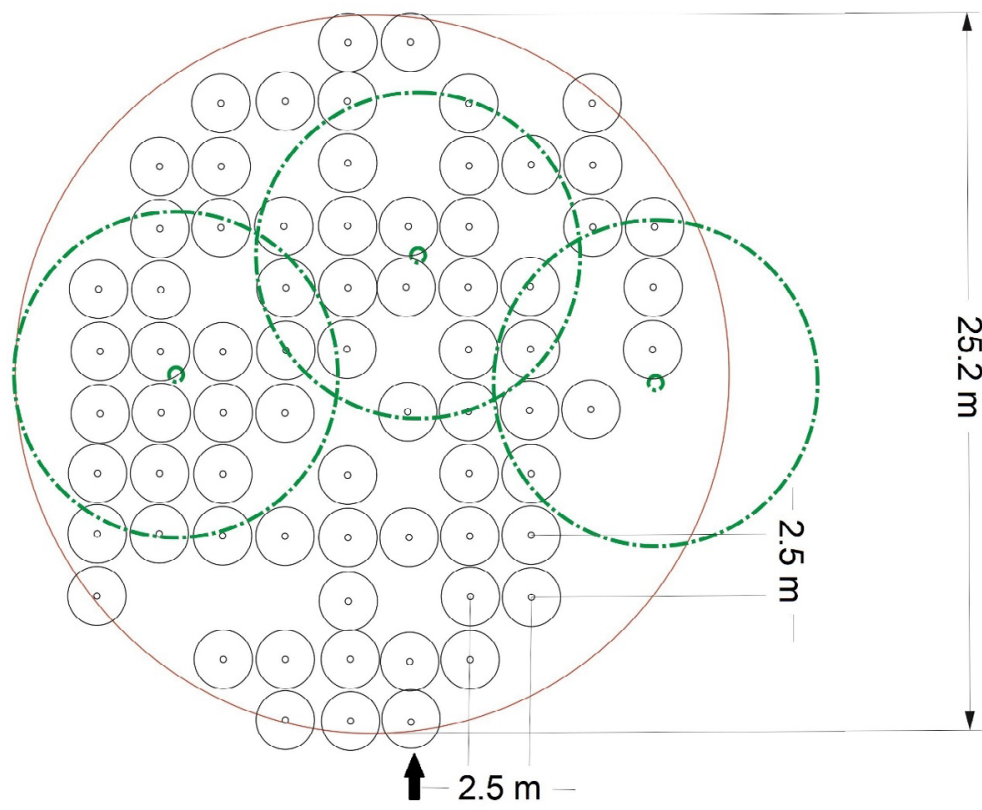

Fig. 3 Sketch of one of the plots sampled during the inventory. Note: the red circle o illustrates the plot boundary; the green dashed $N$ circles and the black circles represent the 3 crown projection area of the Pinus taeda and Cupressus lusitanica trees, respectively; the black arrow indicates the planting line where Cupressus lusitanica trees were measured in terms of total height and crown radii.

The basal area and the total volume per hectare were calculated for both species. The $d_{100}$ and $h_{100}$ of $C$. lusitanica were obtained as the mean diameter and height of the 100 largest-diameter stems ha-1. For P. taeda, $d_{100}$ and $h_{100}$ were calculated as the mean diameter and height since the number of trees sampled in each sample unit was not enough to obtain the $d_{100}$ and $h_{100}$ (average of 3 trees per sample unit)

$$
C A=\left[\left(\frac{\left(R_{1} \cdot R_{2} \cdot \pi\right.}{4}\right)+\left(\frac{\left(R_{2} \cdot R_{3} \cdot \pi\right.}{4}\right)+\left(\frac{\left(R_{3} \cdot R_{4} \cdot \pi\right.}{4}\right)+\left(\frac{\left(R_{4} \cdot R_{1} \cdot \pi\right.}{4}\right)\right]
$$

The crown projection area was summed for both species, based on the mean value, to verify the area occupied by the trees' crowns and then extrapolated to a hectare, based on the number of trees per hectare. Besides, the correlation among C. Iusitanica variables and the distance from $P$. taeda trees was verified through the Pearson method, at $5 \%$ of significance, adopting a radius of $10 \mathrm{~m}$ (as adopted in other studies with shelterwood systems, i.e. Strand et al 2006). Also, the growing space efficiency (GSE), which represents the stem volume growth per unit of projected leaf area (Berrill and O'hara, 2007), was calculated for both species as the ratio of total volume per crown projection area (adapted from O’hara (1988).

\section{RESULTS}

A total of 722 trees of $C$. lusitanica and 30 trees of $P$. taeda were measured on the forest inventory. The diameter, height, individual volume, and crown area variation are shown in Fig. 4. The species C. Iusitanica and P. taeda presented mean dbh values of $12.6 \mathrm{~cm}$ and $58.0 \mathrm{~cm}$, total height of $12.0 \mathrm{~m}$ and $29.8 \mathrm{~m}$, individual volume of 0.1190 $\mathrm{m}^{3}$ and $3.6612 \mathrm{~m}^{3}$ and crown projection area of $2.4 \mathrm{~m}^{2}$ and $128.0 \mathrm{~m}^{2}$, respectively.
The species $P$. taeda presented higher values in all analyzed variables, especially in terms of individual tree volume and crown projection area (Fig. 4). In both basal area and crown projection area, $C$. lusitanica had higher values than $P$. taeda, as a result of a higher number of trees per hectare (Tab. 1). However, even with a density stocking of 60 stems ha-1, the P. taeda' s crown projection area is around $76 \%$ of a hectare, which illustrates the big size of these crowns and their occupation in the horizontal area.

The correlation indexes among the C. Iusitanica variables and distance from $P$. taeda are displayed in Tab. 2. There is not an evident overall relationship between the variables and the distance. A positive significant but weak correlation was detected only for the correlation between $\mathrm{DBH}$ and distance. Although the correlation was not significant for the other C. Iusitanica variables, a negative effect of $P$. taeda cover on $C$. lusitanica height was detected, especially when compared to pure stands (see "Discussion" section).

The growing space efficiency for both species shows a difference between them. Overall, P. taeda was more

Tab. 1 Stocking, basal area, total volume, mean top height, and mean top diameter for C. Iusitanica and $P$. taeda.

\begin{tabular}{cccc}
\hline Variables & C. lusitanica & P. taeda & Total \\
\hline Stocking density $\left(\mathrm{stems}^{2} \cdot \mathrm{ha}^{-1}\right)$ & 1,444 & 60 & 1,504 \\
Basal area $\left(\mathrm{m}^{2} \cdot \mathrm{ha}^{-1}\right)$ & 20.6 & 15.9 & 36.5 \\
Crown projection area $\left(\mathrm{m}^{2} \cdot \mathrm{ha}^{-1}\right)$ & $\sim 26,526$ & $\sim 7,680$ & $\sim 34.206$ \\
Total volume $\left(\mathrm{m}^{3} \cdot \mathrm{ha}^{-1}\right)$ & 171.9 & 219.7 & 391.4 \\
h100 $(\mathrm{m})$ & 13.6 & 29.7 & \\
Ranges & $(10.9-17.3)$ & $(26.0-33.7)$ & \\
& \pm 1.5 & \pm 2.1 & \\
d100 $(\mathrm{cm})$ & 20.9 & 59.4 & \\
Ranges & $(16.0-30.6)$ & $(53.8-70.7)$ & \\
& \pm 2.9 & \pm 4.7 & \\
\hline
\end{tabular}

Note: $\mathrm{h}_{100}=$ mean top diameter $(\mathrm{cm}) ; \mathrm{d} 100=$ mean top diameter $(\mathrm{cm}) ;$ Range $=$ mean (minimum - maximum) values; $\mathrm{s}=$ standard deviation. 

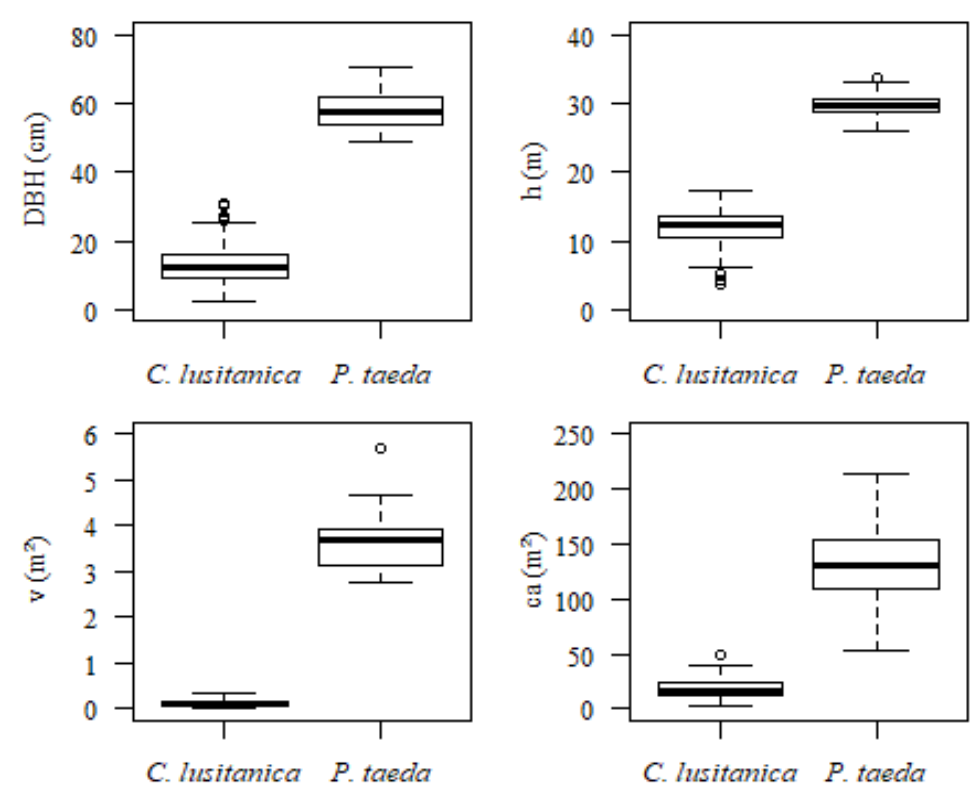

Fig. 4 Data distribution of Cupressus lusitanica and Pinus taeda dendrometric variables in an underplanting system. Note: $\mathrm{dbh}=$ diameter at breast height $(\mathrm{cm}) ; \mathrm{h}=$ total height $(\mathrm{m}) ; \mathrm{v}$ $=$ individual total volume $\left(\mathrm{m}^{3}\right)$ and $\mathrm{ca}=$ crown projection area $\left(\mathrm{m}^{2}\right)$. The whiskers represent the minimum and maximum values of each variable, the bold line represents the median, and the region between the first and third quartiles represents the distribution of $50 \%$ of the data, illustrated by the boxes.
Tab. 2 Correlation values for $\mathrm{d}(\mathrm{cm})$, height $(\mathrm{m})$, individual volume $\left(\mathrm{m}^{3}\right)$, and crown projection area $\left(\mathrm{m}^{2}\right)$ of Cupressus lusitanica in terms of distance (10 m) from Pinus taeda.

\begin{tabular}{cccccc}
\hline Variables & $r$ & d.f. & $t$ & $t_{\text {tab }}$ & $p$-value \\
\hline $\mathrm{d} \times$ distance & 0.10 & 886 & 2.99 & 1.96 & $0.0028^{*}$ \\
$\mathrm{~h} \times$ distance & -0.06 & 160 & -0.85 & 1.97 & 0.3933 \\
$\mathrm{v} \times$ distance & -0.01 & 160 & -0.13 & 1.97 & 0.8904 \\
ca $\times$ distance & -0.10 & 126 & -1.16 & 1.97 & 0.2458 \\
\hline
\end{tabular}

Note: $\mathrm{d}=$ diameter at breast height $(\mathrm{cm}) ; \mathrm{h}=$ total height $(\mathrm{m}) ; \mathrm{v}=$ tree individual volume $\left(\mathrm{m}^{3} \cdot\right.$ stem $\left.^{-1}\right) ; c a=$ crown projection area $\left(\mathrm{m}^{2}\right) ; r=$ correlation coefficient; $d . f$. $=$ degrees of freedom; $t=t$ calculated value; $t$ tab $=t$ value from Student table; $; p$-value $=$ significance correlation value.; ${ }^{*}=$ significant at $5 \%$ level.

efficient in using the growing space than C. Iusitanica. There was a tendency of increasing efficiency with increasing diameter for both species. The $C$. lusitanica trees with up to $25 \mathrm{~m}^{2}$ of crown projection area were the most efficient, while there was a tendency of decreasing efficiency with increasing crown projection area for P. taeda (Fig 5).

The growing space efficiency for both species generally increases with height (Fig. 5). Trees between 11 to 14 meters of height were the most efficient in using the growing space for $C$. Iusitanica. For $P$. taeda, height does not seem to have a linear relation with GSE, with some of the tallest trees presenting both high and low values in this variable

\section{DISCUSSION}

A preliminary analysis of the diameter results suggests that this variable was somehow affected by the $P$. taeda cover. This tendency becomes clear when compared to pure plantations of the species, especially to the results of Venturini et al. (2018) and Souza et al. (2018), which were developed in C. lusitanica stands in the same geographic region (Tab. 3). According to the Farm Forestry New Zealand (2005), in New Zealand, C. Iusitanica plantations are desired to present a mean diameter around 15 to $25 \mathrm{~cm}$ at age 10 under favorable soil and climate conditions. Studies with younger trees had already shown a mean diameter equal to or even higher than the one obtained in this study (Tab. 3).
Studies about the diameter growth of C. Iusitanica and spacing noted that the trees of $C$. Iusitanica with more space tend to show higher diameter, as reported by Kimberley and Nicholas (2006). Indeed, the studies conducted in the same geographic region by Venturini et al. (2018) and Souza et al. (2018) found higher means of diameter under lower stocking density compared to this research. However, even under (Asaye and Zewdie, 2013) or similar (Chinchilla et al., 2011) stocking densities, the mean C. Iusitanica diameter in this study was equal to or lower compared to these two papers with 3-yr younger stands, despite the regional differences among the location of these studies and ours.

The smaller diameter values compared to pure plantations are probably a direct consequence of the $P$. taeda cover effect. The positive correlation of $C$. Iusitanica diameter and distance from $P$. taeda supports this idea. Alem et al. (2015), in Ethiopia, verified that C. Iusitanica presented a higher mean diameter in pure plantation than in a mixed plantation with Eucalyptus camaldulensis, with a difference of almost $10 \mathrm{~cm}$ for the same age. Milne (2006) noted that Cupressus sp., grown with shelter and/or companion species in a mixed stand, are protected against exposure (especially to wind load, because this species is susceptible to toppling), developed better form and decreased branch development, but, as a negative consequence, there could be an effect on diameter growth.

Likewise, the mean height and mean top height of C. lusitanica are lower compared to results on pure plantations of $C$. lusitanica of similar ages even though a significant correlation between C. Iusitanica height and the vicinity to $P$. taeda trees was not identified. In New Zealand, Farm Forestry New Zealand (2005) states that C. Iusitanica can reach $12 \mathrm{~m}$ of height at age 10 under favorable soil and climate conditions. Also, in Alem et al. (2015) study, C. lusitanica exhibited a lower mean height in a mixed stand with E. camaldulensis than in its pure plantation, indicating a possible negative effect of an upper layer for this species on height as well. 


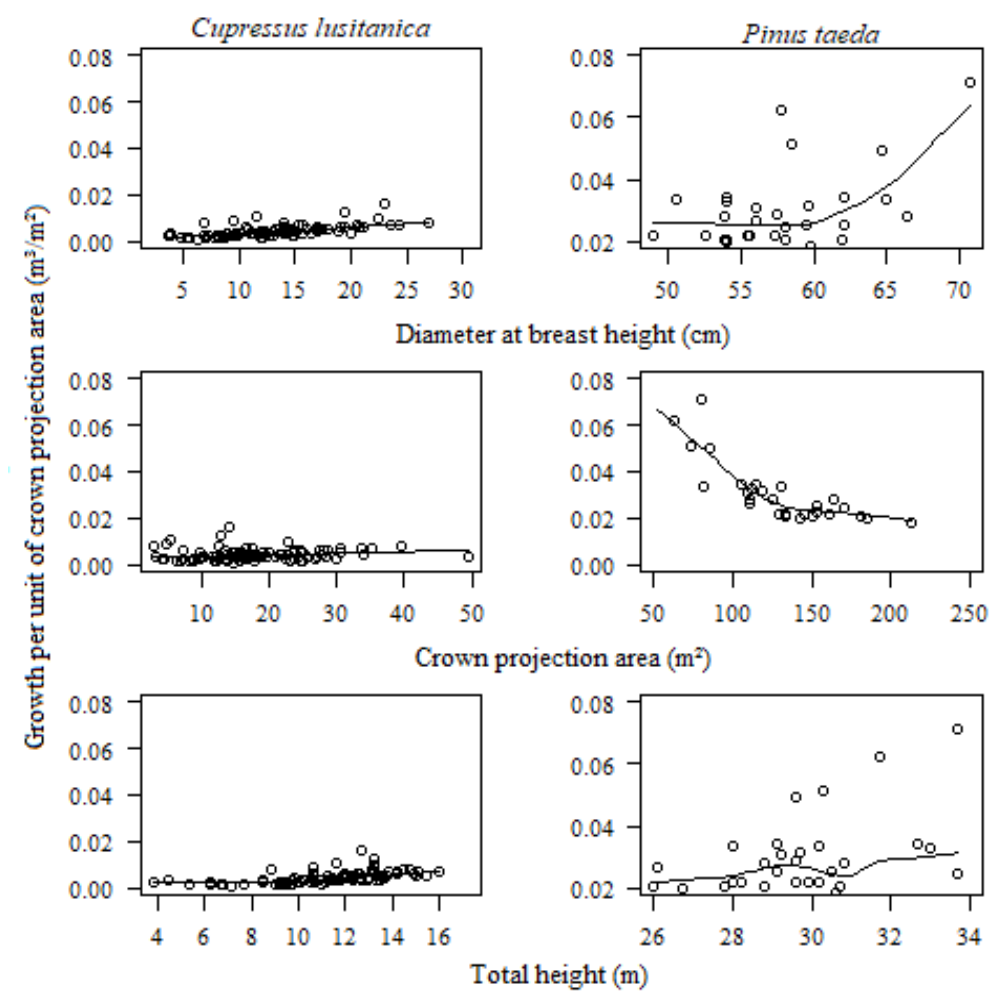

Fig. 5 Growing space efficiency (volume per unit of crown projection area) in relation to diameter (A and B), crown projection area (C and D), and total height (E and F) for Cupressus lusitanica and Pinus taeda, respectively.

Tab. 3 Dendrometric variables of C. lusitanica found in other studies with pure plantations.

\begin{tabular}{cccccccccc}
\hline Country & Age & $\mathrm{S}$ & $\mathrm{DBH}$ & $\mathrm{h}$ & $\mathrm{V}$ & $\mathrm{G}$ & $\mathrm{h}_{100}$ & Authors \\
\cline { 1 - 2 } Ethiopia & 10 & 1,503 & 12.6 & 18.2 & - & 4.7 & - & Asaye and Zewdie (2013) \\
Costa Rica & 10 & 1,293 & 15.5 & - & - & 24.1 & 14.0 & Chinchilla et al. (2011) \\
Costa Rica & 10 & 1,427 & 16.8 & - & - & 14.9 & 14.9 & Chinchilla et al. (2011) \\
Ethiopia & 12 & - & - & - & - & - & 18.8 & Mamo and Sterba (2006) \\
Brazil & 13 & 1,444 & 12.6 & 12.0 & 171.9 & 20.6 & 13.6 & This study \\
Ethiopia & 13 & - & - & - & - & - & 19.2 & Teshome and Petty (2000) \\
Brazil & 14 & 833 & 20.0 & 11.6 & - & - & - & Souza et al. (2018) \\
Ethiopia & 14 & - & - & - & - & - & 20.4 & Mamo and Sterba (2006) \\
Brazil & 15 & 833 & 20.0 & 20.0 & - & 28.2 & - & Venturini et al. (2018) \\
Ethiopia & 15 & 803 & - & - & 220.0 & - & - & Lemenih et al. (2004) \\
Costa Rica & 18 & 408 & 28.0 & 19.2 & - & - & - & Roque et al. (2010) \\
Ethiopia & 27 & 444 & 31.5 & 18.6 & - & - & - & Alem et al. (2015) \\
\hline
\end{tabular}

Note: Age (years); $\mathrm{S}=$ Stocking density (stems ha-1); $\mathrm{d}=\mathrm{dbh}(\mathrm{cm}) ; \mathrm{h}=$ total height $(\mathrm{m}) ; \mathrm{V}=$ total volume $\left(\mathrm{m}^{3}\right.$ ha-1); $\mathrm{G}=$ basal area $\left(\mathrm{m}^{2}\right.$ ha-1); h100 $=\mathrm{mean}$ top height $(\mathrm{m})$.

There are just a few studies about C. Iusitanica growth in pure plantations in Brazil so far (Souza et al., 2018; Venturini et al., 2018). However, a study with this species in Southern Brazil indicates that a higher mean top height was expected for 13-yr-old C. lusitanica based on its guide curve of dominant height growth (Dobner Jr., 2020, unpublished data). On the other hand, the mean top height visualized in this shelterwood system agrees with the site curve index of $14 \mathrm{~m}$ for $C$. Iusitanica at 13 years obtained by the same author.

Some studies have assessed the negative effect of shelter trees on the height growth of understory trees in shelterwood systems. Dobner Jr. et al. (2009) verified that the P. taeda cover affected negatively the growth of $E$. dunnii in terms of collar diameter and total height, with the most pronounced negative effects in a $4 \mathrm{~m}$ ratio from the P. taeda trees. Strand et al. (2006), studying the height growth of seedlings in a Scots pine shelterwood in Sweden, observed that the three assessed species showed reduced height growth due to the vicinity to shelter trees. Also, Valkonen et al. (2002) noticed a reduction between 9 and $17 \%$ of seedling's height growth potential because of retained trees in the upper layer, within a circle of $10 \mathrm{~m}$ radius of each shelter tree, in Finland.

The species summed, together, $36.5 \mathrm{~m}^{2}$.ha-1 in basal area (Tab. 1), and C. lusitanica represents most of it, with $20.6 \mathrm{~m}^{2} \cdot \mathrm{ha}^{-1}$. Compared to the pure plantations (Tab. 3), this value represents a good area occupancy by the trees, buffering the effect of the cover on diameter. This behavior was also observed for C. Iusitanica volume, which showed good results even with the $P$. taeda canopy.

Referring to the crown area and growing space efficiency, the P. taeda trees occupied an area of 7,680 $\mathrm{m}^{2} \cdot \mathrm{ha}^{-1}$, which represents around $76 \%$ of a hectare. When 
compared to the GSE values, the largest trees in the crown projection area showed the lowest growing space efficiencies than smaller-crowned trees, as observed by O'hara (1988) for Douglas-fir. This may be a consequence of shading of lower branches among dominant trees (BERRILL and O'HARA, 2007), or a result from variation in net photosynthesis among trees and variation in carbohydrate allocation to stem volume growth (O'HARA, 1988). For C. Iusitanica, tall trees with small-medium crowns proved themselves as the most efficient producers of volume per unit of crown projection area, which was also verified by Webster and Lorimer (2003) for different species in the USA.

Also, the tendency of improving GSE with an increase in diameter for $P$. taeda shows that growth in diameter, without leading to a significant increase in crown area, enhances the efficiency of volume production per unit of crown projection area (Webster and Lorimer, 2003). The tendency of increasing tree growth efficiency with increasing diameter was also observed by Tschieder et al. (2012), for $P$ taeda, in Argentina.

The GSE measurement applied in our study is useful to describe the efficiency of growing space for both species in terms of stem wood volume, which is the main product desired from this shelterwood. Indeed, the trees with higher values of GSE were the ones with the highest values of total volume as well.

The $P$. taeda basal area data $\left(15.9 \mathrm{~m}^{2} \cdot \mathrm{ha}^{-1}\right)$ and volume $\left(220 \mathrm{~m}^{3} \cdot \mathrm{ha}^{-1}\right)$ are consistent if compared to higher stocking stands in Brazil. Nascimento et al. (2015) reported a basal area of $52.9 \mathrm{~m}^{2}$.ha-1, a volume of $776 \mathrm{~m}^{3}$.ha-1 for a density of 586 stem ha-1 for 33 to 34-yr-old P. taeda. Dobner Jr. (2014) obtained a basal area of $47.7 \mathrm{~m}^{2}$.ha-1 at 30 years for $P$. taeda under an extreme thinning regime, which remained with 150 stem.ha-1 after the last thinning.

In a shelterwood, the canopy's basal area is an important criterion to reduce the shade effect on the overstory trees. Kerr and Haufe (2016) suggest maximum values of canopy trees basal area according to the species' shade tolerance to ensure the success of the trees planted in a shelterwood system, for Britain. Following their criteria, in our case, the maximum basal area of the canopy should be up to $20 \mathrm{~m}^{2}$ ha-1 since both $P$. taeda and C. Iusitanica are classified as shade intolerant (Schultz, 1997; Shimizu et al., 2006). Indeed, shade-tolerant species tend to outperform light-demanding species planted under an existing canopy (Forbes et al., 2014). However, as the P. taeda basal area was $15.9 \mathrm{~m}^{2} \mathrm{ha}^{-1}$, its cover should not be an issue to the $C$. lusitanica growth, and, yet, C. Iusitanica is growing less than in pure plantations

Besides the basal area, another aspect that must be considered when installing a shelterwood system is the canopy stocking density. Agestam et al. (2003) observed that the height growth of Fagus sylvatica was higher in the sparser shelterwood in the first years, but, after that, the highest growth rates were obtained on the clear-cut areas. The authors suggested that this shift was a result of canopy closure, followed by a reduction in light intensity, but it could be also related to the need for protection that F. sylvatica may require in the first years, as they observed higher seedling emergence and less frost damage in the shelterwood.
In this study, a density of 60 stem.ha-1 for the cover layer represents a sparse canopy. Örlander and Karlsson (2010) verified that the seedlings of Picea abies (L.) Karsten, planted under a P. abies and Pinus sylvestris L. cover, showed the highest annual mean height on the shelterwood with canopy density of 80 and 160 stems ha ${ }^{-1}$, which are stocking densities even higher than the present study. We cannot deny that the possible canopy closure by $P$. taeda trees in the last years reduced the light entrance to the understory due to its large crown area values (Fig. 4 and Tab. 5) and, somehow, affected the growth behavior of C. Iusitanica.

Considered the most important limiting aspect to the development of plants in the understory (Coomes and Grubb, 2000), light is, undoubtedly, a key factor for the height growth of trees under a canopy (Strand et al., 2006; Dey et al., 2012; Forbes et al., 2014; Stokes et al., 2020). However, it is been recently found that radiation could be a less decisive stressor for tree height growth (Tishler et al., 2020) than the distance to shelter trees, which is more correlated to the understory trees growth (Strand et al., 2006). In this sense, one explanation to the non-significative correlation between distance from $P$. taeda and C. lusitanica height could be a possible edge effect in some plots closer to the stand boundaries, where some trees would have less influence of P. taeda trees to grow in height" to "where some trees would have less influence of P. taeda on height growth.

Nutrient availability and water supply also affect tree's growth in height. On infertile and drier soils, the belowground competition plays an important rol, while the light is a decisive factor for seedlings' height growth on moist and nutrient-rich soils (Coomes and Grubb, 2000). Thus, in future researches, we suggest including light and soil analysis as well to better understand the growth behavior of species in a system with shelter trees.

Despite the effects of $P$. taeda canopy on $C$. Iusitanica diameter and height, the C. Iusitanica understory showed good results in volume and basal area. Besides, it has established well under the canopy and in a sufficient density to fully stock a future stand, which demonstrates the potential of such a silvicultural system in diversifying an existing forest, as stated by Stokes et al. (2020). In further investigations, we suggest, if possible, analyzing shelterwood stands and monocultures of the species under the same or similar climate and soil conditions, which would promote a better understanding of the growth behavior of the selected species in a shelterwood arrangement in contrast with their pure plantations.

\section{CONCLUSION}

This initial characterization of the shelterwood system showed that the presence of $P$. taeda trees in the canopy somehow affected the growth of $C$. lusitanica in diameter and height. Both species showed a tendency of increasing growing space efficiency with increasing diameter, and $P$. taeda decreased its efficiency with increasing crown projection area. Although the canopy basal area and density in this study were within some established boundaries to ensure the understory establishment and growth success in terms of the light entrance, other variables also play an important role in the understory species growth, 
such as soil fertility and belowground competition, and they should be further investigated in other studies with this silvicultural system.

\section{ACKNOWLEDGMENTS}

The authors wish to thank the private forest enterprise Florestal Gateados for field assistance and support on this project, the Fundação de Amparo à Pesquisa e Inovação do Estado de Santa Catarina (FAPESC) and the research group Forestry Resources Management of the Santa Catarina State University (UDESC) Campus Lages.

\section{AUTHORSHIP CONTRIBUTION}

Project Idea: LRT, DRV, MDJ, MFN

Funding: MDJ

Database: LRT, DRV

Processing: LRT, DRV, MDJ, MFN

Analysis: LRT, DRV, MDJ, MFN

Writing: LRT, DRV, MDJ, MFN

Review: LRT, DRV, MDJ, MFN

\section{REFERENCES}

AGESTAM, E.; EKÖ, P.M.; NILSSON, U.; WELANDER, N.T. The effects of shelterwood density and site preparation on natural regeneration of Fagus sylvatica in Southern Sweden. Forest Ecology and Management, v. 176, n. $1-3$, p. 61-73, 2003

ALEM, S.; PAVLIS, J.; URBAN, J.; KUCERA, J. Pure and mixed plantations of Eucalyptus camaldulensis and Cupressus lusitanica: their growth interactions and effect on diversity and density of undergrowth woody plants in relation to light. Open Journal of Forestry, v. 5, p. 375-386, 2015

ALVARES, C. A.; STAPE, J. L.; SENTELHAS, P. C.; GONCALVES, J. L. M.; SPAROVEK G. Köppen's climate classification map for Brazil. Meteorologische Zeitschrif, v. 22, n. 6, p. 711-728, 2013

ASAYE, Z; ZEWDIE, S. Fine root dynamics and soil carbon accretion under thinned and un-thinned Cupressus lusitanica stands in Southern Ethiopia Plant Soil, v. 366, p. 261-271, 2013

BALANDIER, P.; SINOQUET, $H_{. ;}$FRAK, E.; GIULIANI, R.; VANDAME, $M$ DESCAMPS, S.; COLL, L.; ADAM, B.; PREVOSTO, B.; CURT, T. Six-year time course of light-use efficiency, carbon gain and growth of beech saplings (Fagus sylvatica) planted under a Scots pine (Pinus sylvestris) shelterwood Tree Physiology, v. 27, p. 1073-1082, 2007

BERRILL, J. P.; O'HARA, K. L. Patterns of leaf area and growing space efficiency in young even-aged and multiaged coast redwood stands. Canadian Journal of Forest Research, v. 37, p. 617-626, 2007.

BIBER, P. et al. How sensitive are ecosystem services in European forest landscapes to silvicultural treatment? Forests, v. 6, n. 5, p. 1666-1695, 2015

CARVALHO, P.E.R. Consorciação de espécies nativas valiosas em plantio de Pinus sp. Available at: https://ainfo.cnptia.embrapa.br/digital/bitstream/ item/101431/1/1984-PA77-Carvalho-ConsociacaoEspecies.pdf. Accessed in: January $15^{\text {th }} 2020$

CHINCHILLA, O.; CHAVES, E.; MORA, F. Comparación de crecimientos bajo diferentes intensidades de manejo en plantaciones de Ciprés (Cupressus lusitanica Miller) en dos sítios de Costa Rica. Revista Baracoa, v. 30, p. 1-19. 2011.

COOMES, D. A.; GRUBB, P. J. Impacts of root competition in forests and woodlands: a theoretical framework and review of experiments. Ecological Monographs, v. 70, p. 171-207, 2000.

DEY, D.C: GARDINER, E.S: SCHWEITZER, C.J: KABRICK, J.M: JACOBS, D.F. Underplanting to sustain future stocking of oak (Quercus) in temperate deciduous forests. New Forests, v. 43, p. 955-978, 2012

DOBNER Jr. M.; HIGA, A.R.; SEITZ, R.A. Efeito da cobertura de Pinus taeda L. na proteção contra geadas e no crescimento de plantas jovens de Eucalyptus dunnii Maiden. Floresta, v. 39, n. 4, p. 807-823, 2009.

DOBNER Jr, M. (2014) Impacto do manejo de povoamentos na produtividade e qualidade da madeira de Pinus taeda. 2014. 330 p. PhD thesis Universidade Federal do Paraná, Curitiba.
EMBRAPA. Espécies de Pinus mais plantadas no Brasil. Available at: https://www spo cnptia embrapa.br/conteudo?p p lifecycle =0\&p p $\mathrm{id}=$ conteudoportlet_WAR_sistemasdeproducaolf6_1ga1ceportlet\&p_p_ col_count $=1 \&$ p_p_col_id $=$ column-1\&p_p_state $=$ normal\&p_r_p_-76293187 sistemaProducaold $=3715 \&$ p_r_p_-996514994_topicold $=\overline{3} 229 \& p_{-} p_{-}$ mode=view. Accessed in: February 2nd 2021

FARM FORESTRY NEW ZEALAND Growing C lusitanica for timber Available at: https:/www.nzffa.org.nz/farm-forestry-model/resource-centre/ information-leaflets/farm-forestry-association-leaflet-series/growingcypresses-for-timber/. Accessed in: March $12^{\text {th }} 2019$.

FORBES, A. S.; NORTON, D. A.; CARSWELL, F. E. Underplanting degraded exotic Pinus with indigenous conifers assists forest restoration. Ecological Management and Restoration, v. 16, n. 1, p. 41-49, 2014

KELTY, M.J. The role of species mixtures in plantation forestry. Forest Ecology and Management, v. 233, p. 195-204, 2006

KERR, G.; HAUFE, J. Successful underplanting. Forestry Commission, 2016. 42 p.

KIMBERLEY, M.; NICHOLAS, I. Pruning and thinning. In: NICHOLAS, I. (ed) Best Practices with Farm Forestry Timber Species - No 1: Cypresses. New Zealand Farm Forestry Association, 2006. pp 1-88.

LEMENIH, M.; OLSSON, M.; KARLTUM, E. Comparison of soil attributes under Cupressus lusitanica and Eucalyptus saligna established on abandoned farmlands with continuously cropped farmlands and natural forest in Ethiopia. Forest Ecology and Management, v. 195, p. 57-67, 2004

MAMO, N.; STERBA, $\mathrm{H}$. Site index functions for Cupressus lusitanica at Munesa Shashemene, Ethiopia. Forest Ecology and Management, v. 237, n. $1-3$, p. 429-435, 2006.

MILNE, P. Establishment and management options. In: NICHOLAS, I. (ed) Best Practices with Farm Forestry Timber Species - No 1: Cypresses. New Zealand Farm Forestry Association, 2006. pp 1-88

NASCIMENTO, FA.F: DIAS, AN: FIGUEIREDO FILHO, A: MIRANDA, GM: ARCE, J.E. Sistema de crescimento e produção para povoamentos de Pinus taeda na região Norte de Santa Catarina. Cerne, v. 21, n. 2, p. 235-242, 2015.

O'HARA, K.L. Multiaged silviculture. Oxford University Press, 2014. 232 p.

O'HARA, K.L. Stand structure and growing space efficiency following thinning in an even-aged Douglas-fir stand. Canadian Journal of Forest Research, v. 18 , p. $859-866,1988$

ÖRLANDER, G: KARLSSON C. Influence of shelterwood density on survival and height increment of Picea abies advance growth. Scandinavian Journal of Forest Research, v. 15, p. 20-29, 2000.

PUKKALA, T.; GADOW, K.V. (Ed.) Continuous cover forestry. Springer, 2012. 296 p. ROQUE, R.M.; ACOSTA, F.M.; GARITA, C.S.; JIMÉNEZ, A.B.; ZÚNIGA, L.L.; SEGURA, E.E. Tecnologia de madera de plantaciones forestales: fichas tecnicas. Revista Forestal Mesoamericana Kurú, v. 7, n. 18-19, p. 1-207, 2010.

SCHULTZ, R.P. Loblolly Pine: the ecology and culture of Loblolly Pine (Pinus taeda L.). U.S. Department of Agriculture, 1997. 514 p.

SCOLFORO, J.R.S. Manejo Florestal. UFLA/FAEPE, 1998. 438 p.

SHIMIZU, J.Y.; RIBAS Jr., U.; CANCELA, K.C.; MAIOCHI, R.A. Cedrinho como alternativa para produção de madeira em pequenas propriedades rurais. EMBRAPA Florestas, 2006. 3 p.

SOUZA, E. B. P.; STEPKA, T. F.; HESS, A. F.; BORSOI, G. A.; HOFFMANN, D. VENTURINI, V. C. Modelagem do crescimento e da produção de espécies alternativas na silvicultura regional do planalto serrano de Santa Catarina. In IV Encontro Brasileiro de Mensuração Florestal, 2018, Santa Maria-RS. Anais. IV Encontro Brasileiro de Mensuração
Santa Maria, UFSM, 2018, p. 401-406.

STOKES, V.; KERR, G.; CONNOLLY, T. Underplanting is a practical silvicultural method for regenerating and diversifying conifer stands in Britain. Forestry, p. $1-14,2020$

STRAND, M: LOFVENIUS, M.O; BERGSTEN, U: LUNDMARK, T: ROSVALL, O. Height growth of planted conifer seedlings in relation to solar radiation and position in Scots pine shelterwood. Forest Ecology and Management, v. 224, p. 258-265, 2006.

TESHOME, T.; PETTY, J.A. Site index equation for Cupressus lusitanica stands in Munessa forest, Ethiopia. Forest Ecology and Management, v. 126, p. 339-347, 2000.

TISHLER, M., TULLUS, T.; TULLUS, A.; JÄÄRATS, A.; LUTTER, R.; LUNDMARK, T.; TULLUS, $H$. Effects of shelterwood method and plant stock type on the early growth and survival of pine seedlings in regeneration stands under hemiboreal conditions. Scandinavian Journal of Forest Research, v. 35, p. 85-95, 2020.

TOPANOTTI, L.R.; VAZ, D.R: CARVALHO, S.d.C: RIOS, P.D: TOMAZELLOFILHO, M: DOBNER Jr. M: NICOLETTI, M.F. Growth and wood density of Pinus taeda L. as affected by shelterwood harvest in a two-aged stand in Southern Brazil. Eur J Forest Res, 2021.

TSCHIEDER, E. F; FERNANDEZ, M. E: SCHLICHTER T M : PINAZO M. A. CRECH $E . H$ Influence of growth dominance and individual tree growth efficiency on Pinus taeda stand growth. A contribution to the debate about why stands productivity declines. Forest Ecology and Management, v. 277, p. 116-123, 2012. 
VALKONEN, S: RUUSKA, J: SIIPILEHTO, J. Effect of retained trees on the development of young Scots pine in Southern Finland. Forest Ecology and Management, v. 166, p. 227-243, 2002.

VENTURINI, V. C.; STEPKA, T. F.; HOFFMANN, D.; SOUZA, E. B. P.; HESS, A. F BORSOI, G. A. Classificação da capacidade produtiva de espécies alternativas à silvicultura regional do Planalto Serrano de Santa Catarina. In: IV Encontro Brasileiro de Mensuração Florestal, 2018, Santa Maria-RS, 2018. Anais. Santa Maria UFSM, 2018, p. 133-137.
VENTUROLI, F. FAGG, C.W. FELFILI, J.M. Desenvolvimento inicial de Dypteryx alata Vogel e Myracrodruon urundeuva Allemão em plantio de enriquecimento de uma floresta estacional semidecídua secundária. Biosci. J., v. 27, n. 3, p. 482-493, 2011.

WEBSTER, C. R.; LORIMER, C. G. Comparative growing space efficiency of four tree species in mixed conifer-hardwood forests. Forest Ecology and Management, v. 177, p. 361-377, 2003 